\title{
Profil Sikap Ilmiah Mahasiswa Pada Mata Kuliah Biologi Dasar II
}

\author{
Desi Nuzul Agnafia \\ Pendidikan IPA, STKIP Modern Ngawi \\ Email: desiagnaf@gmail.com
}

\begin{abstract}
Abstrak
Penelitian ini merupakan penelitian deskriptif dengan tujuan untuk menggambarkan sikap ilmiah mahasiswa pada pembelajaran biologi dasar II. Subjek penelitian ini adalah mahasiswa pendidikan IPA semester 2 STKIP Modern Ngawi tahun akademik 2020/2021. Penelitian dilakukan dalam tiga tahapan yaitu tahap awal yaitu perencanaan, tahap kedua yaitu pelaksanaan, dan tahap akhir yaitu analisis data. Instrumen dalam penelitian ini berupa observasi sikap ilmiah mahasiswa dengan indikator rasa ingin tahu, tanggung jawab, kerjasama dan kritis. Berdasarkan hasil observasi didapatkan nilai skor rata rata sikap ilmiah tertinggi adalah indikator tanggung jawab 78,34\% dengan nilai mendapatkan kriteria baik .Indikator rasa ingin tahu dengan nilai $71,21 \%$ mendapatkan kriteria baik. Indikator kerjasama mendapatkan nilai 74,52\% dengan kriteria baik .Indikator kritis mendapatkan nilai $65,27 \%$ dengan kriteria cukup. Rata-rata persentase sikap ilmiah mahasiswa pendidikan ipa semester 2 pada perkuliahan biologi dasar ii tahun akademik 2020/2021 yaitu 72,34\%. Sehingga dapat disimpulkan bahwa sikap ilmiah mahasiswa pada perkuliahan biologi dasar II tergolong kategori baik.
\end{abstract}

Kata Kunci: Sikap Ilmiah, Mahasiswa, Biologi Dasar II

\section{PENDAHULUAN}

Pendidikan merupakan aspek yang berperan penting dalam meningkatkan kesejahteraan kehidupan setiap manusia. Belajar dan mengebangkan potensi diri perlu dilakukan setiap manusia agar mudah dalam memecahkan masalah yang dihadapinya. Banyak dampak positif yang diambil dari proses pendidikan pada diri seseorang. Pendidikan dijadikan sebagai pedoman utama dalam mencapai kualitas diri yang terbukti dengan adanya hasil akademik di sekolah, sikap yang positif di lingkungan keluarga maupun masyarakat. Semua aspek kehidupan tidak akan telrepas dari proses pendidikan. Pendidikan akan berlagsung terus menerus dari manusia lahir ampai akhir hayat. Sesuai dengan Uustem .No. 20 tentang Sistem Pendidikan Nasional bahwa setiap warga negara berhak mendapatkan kesempatan mendapatkan pendidikan sepanjang hayat.

Manusia merupakan makhluk istimewa dibandingkan dengan makhuk ciptaan tuhan yang lain, dimana manusia memiliki akal yang dipergunakan dalam menempuh ilmu pengetahuan, sehingga manusia memiliki kedudukan derajatang tinggi daripada makluk yang lain. Akal yang dimiliki yang setinggi timggiya. Melalui pendidikan tersebut manusia memiliki sikap serta tingkah laku yang baik. Dengan adanya pendidikan tersebut akan tercipta manusia yang berkualitas, handal,. mandiri dalam menghadapi perkembangan teknologi ini.

Sumber Daya Manusia yang berkualitas dibutuhkan dalam menghadapi perkembangan teknologi serta era globalisasi saat ini, oleh karena itu perbaikan pendidikan terus dilakukan pemerintah salah satuya dengan penerapan kurikulum 2013 di sekolahan. Penerapan kurikulum 2013 diharapkan dapat menghasilkan peserta didik yang memiliki kompetensi. Sesuai kurikulum 2013 kompetensi yang harus diiliki siswa diantaranya yaitu siswa mampu mengembangkan rasa ingin tahu, kemampuan dalam berpikir kritis, mengembangkan kreatifitas, kemampuan dalam berpikir kreatif srta adanya sikap ilmiah yang 
harus dimiliki agar tuntas dalam menghadapi permasalahan. Permasalahan permasalahan yang dihadapi dalam pembelajaran dipecahkan melalui metode imiah yang nantnya akan menghasilkan sebuah konsep atau teori. Teoriteori, prinsip-prinsip yang telah ditemukan tersebut dibuktikan dengan kebenarannya melalui sebuah proses. Dalam pembelajaran sains proses tersebut merupakan sebuah satu kesatuan yang harus ada.

Pembelajaran Sains tidak hanya mencakup beberapa terkait pengetahuan saja, tetapi juga mencakup sebuah proses, metode, sikap sikap serta produk. Sains merupakan produk yang berarti bahawa di dalam sains terdapat sebuah fakta, prinsip, konsep . Sains merupakan sebuah proses berarti dalam mendapatkan sebuah ilmu pengetahuan melalui sebuah proses. Sains merupakan sebuah sikap yang berarti dalam sebuah pembelajaran sains didalam nya akan terkandung sikap positif dalam belajar yaitu tekun, jujur, teliti, obyektif, rasa ingin tahu, kritis, terbuka. Biologi merupakan bagian dari ilmu sains, dimana hakikat yang ada di dalam pembelajaran biologi juga merupakan semua aspek yang terkandung dalam pembelajaran sains. Sikap ilmiah dalam pembelajaran wajib dikembangkan melalui metode ilmiah yang dilaksanakan dalam pembelajaran.

Sikap ilmiah merupakan sebuah sikap yang dibentuk seseorang dalam ruang lingkup ilmu alamiah yang bersifat ilmiah. Sikap ilmiah terbentuk melalui proses pembelajaran yang mencakup proses identifikasi, pengalaman serta peranan disekitar. Proses proses tersebut dapat merubah sikap karena adanya sebuah pengalaman atau kontruksi pengetahuan baru dimana dilakukan dengan rutin (Abdi, 2015)

Sikap ilmiah peru dimiliki oleh setiap peserta didik dalam kegiatan pembelajaran karena melalui sikap ilmiah dapat membentuk sikap disiplin, juju, kritis, obyektif, cermat, kreatif, berani beragumentasi, serta memiliki etos kerja yang baik. Carin menjelaskan (Marlina, 2013) yaitu sikap ilmiah yang terbentuk dapat mencegah dari sikap putus asa sehingga dapat bersikap positif dalam sebuah kegagalan. Sikap ilmiah juga sangat penting di terapkan di masyarakat karena dengan sikap ilmiah dapat membentuk pribadi seseorang dalam mendapatkan ide gagasan, adanya pertimbangan yang rasional saat memecahkan masalah yang dihadapi (Harso, 2014).

Mahasiswa merupakan bagian dari civitas akademik yang harus memiliki sikap ilmiah dimana sikap tersebut akan digunakan dalam membekali dirinya menghadapi tuntutan jaman yang semakin berkembang maju serta tanggap terhadap permasalahan yang terjadi disekitar. Pentingnya sikap imiah yang harus dimiliki mahasiswa maka dalam perkuliahan juga perlu adanya proses yang mendukung agar sikap imiah tersebut dapat berkembang. Upaya dalam mempersiapkan mahasiswa yang berkualitas dan berkompeten maka perlu dilakukan dasar sebagai profil untuk mengetahui kemampuan dalam setiap diri mahasiswa sebagai langkah seanjutnya yang akan diberikan suatu proses pembelajaran yang sesuai, maka dilaksanakan penelitian profil sikap ilmiah mahasiswa dalam pembelajaran Biologi Dasar II.

\section{METODE}

Penelitian yang dilakukan ini merupakan penelitian deskriptif yaitu penenlitian yang memberi gambaran terkait individu tentang keadaan atau gejala yang terjadi yaitu sikap ilmiah. Penenitian deskriptf merupakan penelitian yang dilakukan untuk mengetahui nilai variabel mandiri, baik satu variabel atau lebih untuk menjawab pertanyaan dari rumusan masalah penelitian (Sugiyono, 2013). Berdasarkan Sudjana menjelaskan bahwa penelitian deskriptif merupakan penelitian yang mendeskripsikan suatu gejala, peristiwa, 
kejadian yang terjadi pada saat sekarang (Sudjana, 2007).

Prosedur penelitian terdiri dari 3 tahapan. Tahapan pertama yaitu tahap persiapan yaitu tahap dalam melakukan study literatur dan meruuskan permasalahan. Pada tahap pertama ini juga ditentukan lokasi serta subyek penelitian kemudian penyusunan,perancangan srta evauasi dari instrumen. Studi literatur dengan melaksanakan observasi awal. Tahapan kedua yaitu tahap proses pelaksaan di lapangan yaitu sesuai dengan rancangan penelitian yaitu peaksananan pembelajaran pada mata kuliah biologi dasar 2. Pada tahap pelaksanaan juga dilakukan tindakan observasi sesuai dengan indikator yang telah ditetapkan. Tahapan akhir merupakan tahapan mengolah data dan menganalisisnya sesuai dengan metode yang sesuai. Hasil dari tahapan analisis data dibuat pembahasa serta menarik kesimpulan serta saran. Kemudian dari keselruhan akan dibuat dalam laporan hasil penelitian profil sikap ilmiah.

Penelitian yang dilakukan dilaksanakan pada mahasiswa Pendidikan IPA semester 2 tahun akademik 2020/2021 di STKIP Modern Ngawi dengan jumlah mahasiswa sebanyak 27 orang. Penelitian dilakukan pada bulan Februari sampai April 2021. Data dikumpulkan dengan instrumen berupa lembar observasi yang memuat indikator sikap ilmiah dengan perteuan 4 kali pada mata kuliah biologi dasar 2 .

Indikator sikap ilmiah yang diamati dalam penelitian ada 4 aspek yaitu rasa ingin tahu, tanggung jawab, kerjasamadan teliti. Pada Pelaksanaan observasi dilakukan oleh 3 orang observer. Sebelum pelaksanaan observasi dilakukan penyamaan apersepsi kepada para observer terkait indikator yang diamati sehingga data yang dihasilkan akan valid. Lembar observasi akan diisi oleh observer dengan memberikan tanda checklist yang sesuai dengan pengamatan dilapangan. Dari perolehan skor mahasiswa yang didapatkan akan dihasilkan data yang diolah dan di analisis dan kemudian menentukan kriteria nilai sikap imiah.

Hasil data yang diperoleh dipersentasekan dengan rumus berikut:

$$
\mathrm{P}=\frac{\mathrm{F}}{\mathrm{N}} \times 100 \%
$$

Keterangan :

$\mathrm{P}$ : Persentase

F : Frekuensi

$\mathrm{N}$ : Banyaknya sampel

(Sudjiono, 2011)

Hasil dari persentase dikategorikan berdasarkan kriteria penilian sikap ilmiah dapat dilihat pada tabel 1 .

Tabel 1. Kriteria Nialai sikap Ilmiah

\begin{tabular}{|l|l|}
\hline \multicolumn{1}{|c|}{ Nilai } & \multicolumn{1}{c|}{ Kriteria } \\
\hline 81 ---- 100 & Sangat Baik \\
\hline 71 ---- 80 & Baik \\
\hline 61 ---- 70 & Cukup \\
\hline 51 ---- 60 & Kurang \\
\hline$<51$ & Kurang Sekali \\
\hline
\end{tabular}

(Riduwan, 2009)

\section{HASIL PENELITIAN DAN PEMBAHASAN}

Sikap ilmiah yang diukur yaitu rasa ingin tahu, tanggung jawab, kerjasamadan teliti. Hasil analisis data diperoleh nilai persentase rata rata di kelas pada sikap ilmiah yang diukur. Sikap ilmiah mahasiswa pada pembelajaran biologi dasar 2 dapat dilihat pada tabel 2. 
Tabel 2. Rata rata sikap ilmiah mahasiswa dalam pembelajaran biologi dasar 2 .

\begin{tabular}{|l|l|}
\hline Sikap Ilmiah & Rata -rata \\
\hline Rasa Ingin Tahu & 71.21 \\
\hline Tanggung Jawab & 78.34 \\
\hline Kerjasama & 74,52 \\
\hline Kritis sikap & $\mathbf{7 2 , 3 4}$ \\
\hline $\begin{array}{l}\text { Rata-rata } \\
\text { ilmiah keseluruhan }\end{array}$ \\
\hline
\end{tabular}

Sikap ilmiah mahasiswa yang ditunjukan pada tabel 2 terlihat bahwa sikap ilmiah setiap indikator memiliki skor hasil yang berbeda beda. Sikap tanggung jawab memiliki nilai paling timggi daripada indikator sikap yang lainnya. Sikap tanggung jawab menghasilkan rata rata sebesar 78,34 \%. Sikap kerjasama memperoleh hasil skor rata rata sebesar 74, 52 $\%$, sikap rasa ingin tahu memperoleh hasi skor rata rata sebesar $71,21 \%$, sikap kritis memperoleh hasil skor rata-rata sebesar $65,27 \%$.

Berikut merupakan kriteria dari perolhan hasil sikap ilmiah mahasiswa yang dapat dilihat pada tabel 3.

Tabel.3 Kriteria Sikap Ilmiah Mahasiswa

\begin{tabular}{|l|l|}
\hline Sikap Ilmiah & Kiteria \\
\hline Rasa Ingin Tahu & Baik \\
\hline Tanggung Jawab & Baik \\
\hline Kerjasama sikap & Baik \\
\hline Kritis & Cukup \\
\hline $\begin{array}{l}\text { Rata-rata ilmiah keseluruhan } \\
\text { ilmik }\end{array}$ \\
\hline
\end{tabular}

Tabel 3 terlihat bahwa indikator sikap rasa ingin tahu memiliki kriteria baik, indikator tanggung jawab memiliki kriteria baik, indikator kerjasam dengan kriteria baik, sedangkan imdiktaror kritis dengan indikator cukup. Berdasarkan hasil indikator yang diamati diperoeh hasil rata rata sikap imiah keseluruhan dengan kriteria baik. Gambaran trkait hasil perolehan sika ilmiah dapat di lihat pada gambar 1 .

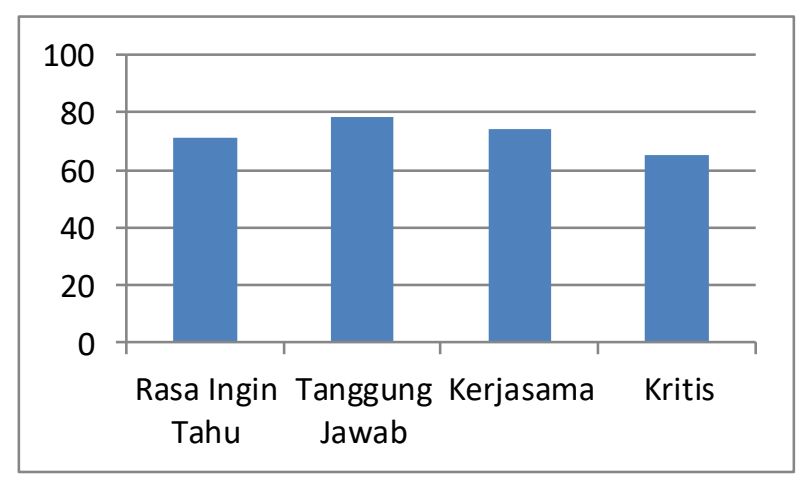

Gambar.1. Rata rata sikap ilmiah mahasiswa dalam pembelajaran biologi dasar 2

Pada pembelajaran pekuliahan biologi dasar 2 dalam setiap pertemuannya mengalami kenaikan untuk setiap indikatornya. Sikap tanggung jawab memiliki skor tertinggi terlihat dari setiap mahasiswa yang mengumpulkan tugas dalam setiap pertemuan. Sikap tanggung jawab juga terlihat dari pembuatan laporan praktikum mahasiswa. Meskipun demikian masih ada beberapa mahasiswa yang belum tepat waktu dalam pengumpulan tugas. Penyebab lain bahwa mahasiswa juga sebagian tidak tepat waktu dalam pengumpulan lapran dikarenakan para mahasiswa terebut belum terbiasa dalam penulisan laporan ilmiah sehingga masih kesulitan dan memerlukan waktu panjang dalam penyususnannya. Indikator sikap tanggng jawab yang kedua yaitu pelaksanaan praktikum atau presentasi kelas, pada indikator ini semua kelompok bertanggung jawab dalam melaksanakan praktikum dan presentasi dikelas. Indikator 
sikap tanggung jawab yang ketiga yaitu dalam diskusi kelompok aktif dalam berdiskusi, memberikan ide gagasan dalam memecahkan persoalan, serta terbuka dalam menerima pendapat teman lain. Indikator tanggung jawab yang lain juga bisa terlihat saat diskusi kelas atau pertanyaan yang di ajukan oleh dosen, dalam kegiatan ini mahasiswa bisa juga mengajukan pertanyaan, mengajukan pendapat atau ide gagasannya di presentasi kelas, serta terbuka dalam menerima kritikan kelomok lain. Indikatr keempat terlhat dari mahasiwa yang tepat waktu dalam melaksanakan pembelajaran,tepat waktu dalam mengumpulkan tugas, bertanggung jawab dalam menyiapkan alat bahan praktikum, serta kebersihan setelah selesai pembelajaran. Selama proses pembelajaran biologi dasar 2 terlihat semua mahasiswa berusahan dalam melaksanakan tanggung jawabnya dalam menyelesaikan tugas masing masing baik individu maupun kelompok.

Sikap tanggung jawab harus dimiliki oleh para ilmuwan. Sebagai ilmuwan masalah moral dan akhlak sangat diperlukan yaitu yang terwujud dalam bentuk sikap tanggung jawab. Imu pengetahuan telah memebawa perubahan besar pada era jaman modern ini tetapi imu yang memiliki pondasi kokoh dan kuat harus dijadikan sebagai penyelamat atau pedoman masyarakat, disinilah letak tanggung jawab ilmuwan harus tetap dimiliki dimana berkaitan dengan moral dan akhlak. Seorang ilmuwan harus memiliki aklak yang terwujud sari sikap tanggung jawab agar selalu berkehendak (Tim Dosen , 2010)

Sebagai makhluk tuhan yang istimewa yaitu memiki akal pikiran, yang hidup bersama dengan makhluk lain, haruslah manusia menjaga kelestarian dalamkeseimbangan tidak sebaliknya untuk mengekploitasi atau merusaknya. Oleh sebab itu tanggung jawab harus di munculkan dalam setiap peserta didik agar nantinya manusia juga bertanggungjawab dalam kehidupan sekitar sebagai wujud sikap imuwan.

Sikap ilmiah rasa ingin tahu ada di urutan kedua untuk perolehan skor dengan predikat baik. Sikap rasa ingin tahu terlihat dari antusias atau semangat mahasiswa dalam memperhatikan pembelajaran serta antusias dalam melakukan percobaan. Indikator dari sikap rasa ingin tahu yaitu mencari informasi dari berbagai sumber referensi. Indikator ketiga yaitu terlihat dari mencoba alternatif dalam memecahkan persoalan. Indikator keempat yaitu mengajukan pertanyaan pada permaslahan yang disampaikan. Sebelum ke jenajng perkuliahan mahasiswa rata rata jarang melakukan percoban dikarenakan latar belakang jurusan di sekolah bukan di bidang ipa, sehingga mahasiswa berantusias dalam melakukan percobaan. Yunita menjelaskan bahwa rasa ingin tahu yang tinggi terhadap konsep baru yang dipelajari merupakan salah satu sikap imiah yang tercermin dari peserta didik. Carin dalam bukunya menjelaskan bahwa manusia memiki rasa dorongan dan kebutuhan dalam mencari suatu jawaban atau pemecahan masalah terkait pertanyaan atau persoalan dunia begitu juga manusia juga selalu mencoba dalam memecahkan suatu permasalahan yang dihadapi terkait perkembangan ilmu pengetahuan (Carin, 1997).

Kementerian Pendidikan dan Kebudayaan menjelaskan bahwa rasa ingin tahu adalah cara dalam berpikir, bersikap, dan berperilaku yang mencerminkan rasa penasaran dan rasa keingintahuan tentang segala sesuatu yang ingin didengar, ingin di lihat, dan ingin dipelajarai secara mendalam (Kemendikbud, 2018). Rasa ingin tahu siswa harus digali tidak muncul dengan sendirinya,agar muncu dengan baik maka perlu dirangsang atau dilatih (Iman, 2011). Sikap rasa ingin tahu yang tinggi siswa memembuktikan bahwa siswa tersebut tertarik 
terhadap materi atau informasi yang di sampaikan dan tertarik untuk mempelajari materi tersebut (Gruber, Gelman, \& Ranganath, 2014). Sikap ilmiah kerjasama diperoleh hasil rata rata dengan persentase $74,52 \%$ dengan kriteria baik. Sikap krjasma dilakukan dengan baik oleh mahasiswa saat pembelajaran berlangsung. Sikap ilmiah kerjasama terlihat dari mahasiswa yang melakukan kerjasama antar kelompoknya dalam memecahkan masalah serta melaksanakan kegiatan praktikum. Sikap kerjasama juga erlihat dari adanya kekompakan setiap kelompok yaitu adanya aktifitas berdiskusi saling memberikan pendapat, menghargai pendapat temannya, menerima hasil keputusan atau pendapat yang berbeda.

Sikap iliah kritis apada pembelajaran biologi dasar II menunjukkan rata rata persntase sebesar 65, $27 \%$ dengan kriteria cukup. Pada sikap ilmiah kritis merupakan perolehan terendah dibandingkan dngan sikap ilmiah yang lainnya. Sikap ilmiah kritis dapat terlihat dari beberpa pertanyaan yang di ajukan oleh mahasiwa. Indikator lain dari sikap kritis yaitu mahasiswa mendiskusikan hasil pemecahan masalahan dan hasil dari paraktikum , mahasiswa juga bisa menganalisis hasil dari data yang didapatkan. Saat diskusi bersama maahsiswa juga terlihat ada yang memberikan hasil data kelompoknya sebagai tanggapan atau pembenaran saat ada mahsiswa lain yang keliru dalam menyampaikan pendapatanya.

Sikap ilmiah rata rata dalam kriteria baik meskipun demikian perlu ditingkatkan kembali dalam proses belajar selanjutnya. Sesuai yang dijabarkan yunita dan Fakhrudin (2014) bahwa setiap peserta didik yang memiliki sikap ilmiah tinggi akan memudahkan kelancaran dalam proses berpikir sehingga pserta didik tersebut sealu termotivasi dalam mendapatkan prestasi serta memiliki komitmen yang tinggi dalam mencapai keberhasilan. Prestasi belajar yang baik merupakan keberhasilan yang dcapai oleh para peserta didik dalam bidang pendidikan. sikap imiah berkaitan dengan prestasi belajar (Olasehinde, 2014)

Slameto menjelaskan bahwa sikap adalah faktor internal yang berpengaruh terhadap belajar. Sikap peserta didik dalam belajar dipengaruhi oleh faktor penting lainnya sehingga peserta didik menentukap sikap yang mana yang akan terbentuk (Slameto, 2015). Sikap ilmiah akan sering muncul jika diberikan sebuah rangsanagan serta dibiasakan terus menerus (Lang \& Evans, 2006). Sikap ilmiah akan muncul melalui kegiatan pembeljaran yang memberikan pengalaman langsung kepada peserta didik seperti percobaan, observasi, penemuan (Sulviana, Jufri, \& Japa, 2018). Sikap rasa ingin tahu akan terbentuk dalam suatu kegiatan penyelidikan ilmiah dimana akan menggali lebih dalam terkait bagaimana sikap rasa ingin tahu dan dalam proses tersebut akan mempengaruhi ingatan atau membangun konsep seseorang (Gruber, Gelman, \& Ranganath, 2014). Sejalan dengan penjelasan (Suhandak, 2014) bahwa sikap rasa ingin tahu akan terbentuk dengan adanya kegiatan penyelidikan, mencari tahu, menemukan sehingga akan muncul antusias dari peserta didik dalam mempelajari sesuatu.

\section{PENUTUP}

\section{Simpulan}

Berdasarkan hasil analisis data dan pembahasan, maka dapat diperoleh kesimpulan bahwa secara umum rata rata sikap ilmiah mahasiswa semester 2 pada pembelajaran biologi dasar ii dengan kriteria baik. Meskipun demikian sikap ilmiah mahasiswa masih perlu ditingkatkan lagi terutama pada indikator kritis yang menapatkan kriteria cukup. 


\section{Saran}

Penelitian yang dilakukan perlu ada tindak lanjut penelitian selanjutnya terutama untuk mengasah sikap ilmiah agar lebih dapat dikembangkan oleh mahasiswa.

\section{DAFTAR PUSTAKA}

Abdi, C. O. (2015). Pengaruh Model Pembelajaran Siklus Belajar(Learning Cycle) $7 e$ Terhadap Sikap Ilmiah Dan Hasil Belajar Biologi Peserta Didik Sman 1 Pringgabaya Tahun Ajaran 2015/2016. Mataram: Universitas Mataram.

Carin. (1997). Teaching Modern Science. New Jersey: Merrill Publishing.

Filsafat, T. D. (2010). Filsafat Ilmu. Yogyakarta: Liberty.

Gruber, M., Gelman, B., \& Ranganath, C. (2014). States of curiosity modulate hippocampus-dependent learning via the dopaminergic circuit. Neuron, 84, 486-496.

Harso, d. (2014). Pengaruh Model Pembelajaran Heuristik Vee terhadap Pemahaman Konsep Fisika dan Sikap Ilmiah Siswa Kelas X SMA Negeri 2 Langkessss Rembong. Jurnal: $e$ journal Program Pascasarjana. Universitas Pendidikan Ganesha Program Studi, 4, 1-12.

Iman, S. (2011). Kemampuan Berpikir Kreatif dan Rasa Ingin Tahu Melalui Pembelajaran Matematika. Prosiding Seminar Nasional.

Kemendikbud. (2018). Permendikbud RI No. 352018 tentang perbahan atas pearaturan menteri pendidikan dan kebudayaan tentang kurikulum 2013 SMP/MTs. Jakarta.

Lang, H., \& Evans, D. (2006). odels, Strategies, and Methods for Effective Teaching. USA: Pearson Education Inc. Marlina, R. (2013). Pemanfaatan Lingkungan Lokal dalam Kegiatan Laboratorium Berbasis Inkuiri Terhadap Sikap Ilmiah Mahasiswa Calon Guru Biologi. Jurnal Visi Ilmu Pendidikan 10 (1), 1-10.
Olasehinde, K. J. (2014). Scientific Attitude, Attitude to Science and Science Achievement of Senior Secondary School Students in Katsina. Journal of Educational and Social Research,, 4, 452- 445.

Riduwan. (2009). Metode \& teknik menyusun proposal penelitian. Bandung: Alfabeta.

Slameto. (2015). Belajar dan Faktor Faktor yang mempengaruhinya. Jakarta: Rineka Cipta.

Sudjana, e. (2007). Penelitian dan Penilaian Pendidikan. Bandung: Sinar Baru.

Sudjiono, A. (2011). Pengantar Evaluasi Pendidikan. Jakarta: PT.Raja Grafindo Persada.

Sugiyono. (2013). Metode Penelitian Pendidikan pendekatan Kuantitatif, Kualitatif. Bandung: Alfabeta.

Suhandak, M. (2014). Keefektifan Metode Inkuiri dalam Pembelajaran Sistem Persamaan Linear Dua Variabel ditinjau Dari Prestasi Dan Curiosity. Indonesian Digital Journal of Mathematics and Education, 1.

Sulviana, A., Jufri, A., \& Japa, L. (2018). Pengaruh model pembelajaran5E terhadap kesadaran metakognitif dan sikap ilmiah siswa pada mata pelajaran IPA di MTsN 1 Mataram. Seminar Nasional Pendidikan Biologi, (hal. 2025). Mataram.

Tim Dosen , F. (2010). Filsafat Ilmu. Yogyakarta: Liberty. 